6. The internal stability of the States which are signatories to this Declaration is a prerequisite condition of the security of their frontiers. To this end, each State shall take appropriate steps to strengthen its democratic institutions and achieve national harmony on the basis of respect for human rights and fundamental freedoms.

7. The signatories to this Declaration are counting on neighbouring States and the international community in general for their support and understanding of the situation.

\title{
KUALA LUMPUR DECLARATION ON HUMAN RIGHTS*
}

\section{Preamble}

Whereas, the peoples of ASEAN recognize that all human beings are created by the Almighty, and possess fundamental rights which are universal, indivisible and inalienable;

Whereas, the peoples of ASEAN are born free and equal with full dignity and rights and are endowed with reasoning and conscience enabling them to act responsibly and humanely towards one another in a spirit of brotherhood;

Whereas, the peoples of ASEAN realize that human beings cannot live alone but in harmony with one another with nature and their environment to achieve complete fulfilment of their aspirations in a just society based on harmonious and balanced economic, social, political and cultural developments;

Whereas, the peoples of ASEAN recognize that human rights have two mutually balancing aspects; those with respect to rights and freedom of the individual, and those which stipulate obligations of the individuals to society and State;

Whereas, the peoples of ASEAN accept that human rights exist in a dynamic and evolving context and that each country has inherent historical experiences, and changing economic, social, political and cultural realities and value system[s] which should be taken into account.

Whereas, the peoples of ASEAN are convinced that human beings [have] a right to development and freedom from poverty, hunger, illiteracy, ignorance, injustice, diseases and other human miseries;

Whereas, the peoples of ASEAN reaffirm the observance of the United Nations Universal Declaration of Human Rights Charter, and the Vienna Declaration and Program of Action of 25 June 1993;

Whereas, the continuing progress of ASEAN in freeing its people from fear and want has enabled them to live in dignity;

Whereas, ASEAN seeks to further enhance its role in promoting a world order based on freedom, peace and social justice through international, regional and bilateral cooperation.

* Approved by the Second Plenary Session of the 14th General Assembly of the ASEAN InterParliamentary Organization, October 1993. 


\section{Part I HUMAN RIGHTS DECLARATION: Principles}

\section{Article 1}

All human beings, individually and collectively, have a responsibility to participate in their total development, taking in account the need for full respect of their human rights as well as their duties to the community. Freedom, progress and national stability are promoted by balance between the rights of the individual and those of the community.

\section{Article 2}

All human beings, without distinction as to race, colour, sex, language, religion, nationality, ethnic origin, family or social status, or personal convictions have the right to live in dignity and to enjoy the fruits of development and should, on their part, contribute to and participate in it.

\section{Article 3}

All human beings have the right to self-determination. By virtue of this right, they freely determine their political status and may pursue their economic, social, political and cultural development.

\section{Article 4}

Each Member State has the right to development based on its own objectives, to set its own priorities, and to decide the ways and means of realizing its development without external interference.

\section{Article 5}

Universal promotion and protection of human rights should take place in the context of international cooperation based on respect for national sovereignty, territorial integrity and non-interference in the internal affairs of States, and human rights should not be used as a conditionality for economic cooperation and development assistance.

\section{Article 6}

National development shall be founded on the basis of respect for the dignity and value of human beings, which required the elimination of all forms of inequality, exploitation, colonialism, racism, and the implementation of civil, political, economic, social and cultural rights without discrimination. 


\section{Part II: FUNDAMENTAL HUMAN RIGHTS}

\section{Article 7}

Everyone has the right to life. No one shall be deprived of such right except in accordance with the law.

\section{Article 8}

Everyone has the right to freedom of thought, opinion, conscience and religion, these rights include freedom of teaching, practice, worship and observance, both in private and public, individually or in community with others.

\section{Article 9}

Everyone has the right to property, liberty and security of person. No one shall be deprived of these rights except in accordance with law.

\section{Article 10}

Any violation of these fundamental human rights should be redressed in accordance with law.

\section{Part III: BASIC RIGHTS AND DUTIES OF CITIZENS AND STATES}

\section{Article 11}

Everyone is equal before the law and is entitled to protection of the law without any discrimination.

\section{Article 12}

Everyone has the right to freedom of expression which carries inherent duties and responsibilities.

\section{Article 13}

Everyone has the right to freedom of association. No restrictions may be imposed on the exercise of this right other than those prescribed by law. 


\section{Article 14}

Everyone charged with a criminal offence has the right to be presumed innocent until proven otherwise according to law.

\section{Article 15}

Every citizen has the right and should have the opportunity, without unreasonable restrictions, to participate in the conduct of public affairs directly or indirectly through freely chosen representatives, to vote and to be elected to public office.

\section{Article 16}

It is the right and duty of each Member State to formulate appropriate and sustainable national development policies that aim at the constant improvement of the well-being for all its citizens on the basis of active, free and meaningful participation in development and in the fair distribution of the benefits resulting therefrom.

\section{Article 17}

Each Member State should undertake all neccessary measures for the realization of the right to development and shall ensure equality of opportunity for all its citizens in their access to basic resources, education, health services, food, housing, employment, public services and the fair distribution of income.

\section{Article 18}

Each Member State should undertake appropriate economic, social, political, technical and cultural measures in order to promote social justice.

\section{Article 19}

Each Member State has the duty to encourage and facilitate the participation of all citizens in all spheres of development to ensure full realization of human rights.

\section{Article 20}

It is the task and responsibility of each Member State and every citizen to ensure the promotion, implementation and protection of human rights. 


\section{Article 21}

It is likewise the task and responsibility of Member States to establish an appropriate regional mechanism on human rights.

\section{Article 22}

Each Member State and its citizens shall endeavour to exercise the aforementioned rights and duties subject only to such limitations as are determined by law in respect of these rights and duties to meet the just requirement of morality, public order and the general well-being of society. 